\title{
POLA SEBARAN ALAMI ANGGREK (Orchidaceae) DI CAGAR ALAM PADANG LUWAY KABUPATEN KUTAI BARAT
}

\author{
Fitriany $\mathbf{M}^{1}$, Muhammad Sumaryono ${ }^{2}$, dan Ali Suhardiman ${ }^{3}$ \\ ${ }^{1}$ Fakultas Kehutanan, Universitas Mulawarman, Jl Ki Hajar Dewantara Kampus Gunung \\ Kelua, Samarinda, Kalimantan Timur, Indonesia 75119, nomor telp/fax (0541) 735089. \\ ${ }^{2}$ Balai Konservasi Sumber Daya Alam Kalimantan Timur, Jl. Teuku Umar No. 17 Karang \\ Anyar Kecamatan Sungai Kunjang Samarinda, Kalimantan Timur, Indonesia 75243, \\ nomor telp/fax (0541) 743556. \\ E-Mail: fiandri00@gmail.com
}

\begin{abstract}
ABSTRAK
Pola Sebaran Alami Anggrek (Orchidaceae) Di Cagar Alam Padang Luway Kabupaten Kutai Barat. Cagar Alam Padang Luway merupakan salah satu habitat anggrek (Orchidaceae) di Kalimantan Timur. Untuk melakukan kegiatan pelestarian diperlukan data dan informasi dasar tentang faktor-faktor ekologi spesies anggrek yang ada serta pola penyebarannya sehingga dapat menjadi dasar pertimbangan dalam pengelolaannya. Penelitian ini dilakukan untuk mengetahui sebaran Anggrek dan komposisi spesies anggrek dengan menggunakan metode analisis vegetasi. Areal penelitian merupakan pulau-pulau anggrek yang terdapat di Cagar Alam Padang Luway. Berdasarkan hasil penelitian berdasarkan Indeks Dispersi Morisita Anggrek rata-rata mengelompok dan Quadrat Analysis sebaran anggrek mengelompok. Sedangkan nilai INP tertinggi adalah Coelogyne pandurata Lind 47,675 yang paling rendah adalah Bulbophylum sp. 1,686 dan Dendrobium sp. 1,686. Sebaran jenis-jenis anggrek di Cagar Alam Padang Luway hasil penelitian ini dapat dijadikan dasar pertimbangan dalam pengelolaan Cagar Alam Padang Luway dimasa yang akan datang.
\end{abstract}

Kata kunci : Cagar Alam Padang Luway, Anggrek, Hutan Kerangas dan Analisis Vegetasi.

\begin{abstract}
Natural Distribution Pattern Orchid (Orchidaceae) in Padang Luway Nature Reserve, West Kutai Regency. Padang Luway Nature Reserve is one of the orchid habitats (Orchidaceae) in East Kalimantan. To carry out conservation activities, basic data and information are needed about the ecological factors of the existing orchid species and their distribution patterns so that they can become a basis for consideration in their management. This research was conducted to determine the distribution of orchids and orchid species composition using vegetation analysis methods. The research area is orchid islands found in Padang Luway Nature Reserve. Based on the results of the study based on the Morisita Dispersion Index, the average group cluster and Quadrat Analysis of cluster orchid distribution. While the highest INP value is Coelogyne pandurata Lind 47,675, the lowest is Bulbophyllum sp. 1,686 and Dendrobium sp. 1,686. Distribution of types of orchids in the Padang Luway Nature Reserve the results of this study can be used as a basis for consideration in the management of the Padang Luway Nature Reserve in the future.
\end{abstract}

Key words : Padang Luway Nature Reserve, Orchid, Kerangas Forest, and Vegetation Analysis.

\section{PENDAHULUAN}

Menurut Peraturan Pemerintah Nomor 28 Tahun 2011 Cagar Alam merupakan kawasan suaka alam karena keadaan alamnya mempunyai kekhasan tumbuhan, satwa dan ekosistemnya atau ekosistem tertentu yang perlu dilindungi dan perkembangannya secara alami.
Kawasan cagar alam merupakan jenis kawasan konservasi yang memiliki tingkat perlindungan yang sangat tinggi dibandingkan dengan kawasan konservasi lainnya.

Cagar Alam Padang Luway merupakan salah satu habitat anggrek di Kalimantan Timur. Di cagar alam ini 
telah ditemukan 57 (lima puluh tujuh) spesies Anggrek alam dan salah satu spesies Anggrek yang ada di sana adalah Anggrek Hitam (Coelegyne pandurata Lindl.) (Halim, 2010). Di Indonesia status perlindungan anggrek diatur dalam UU No. 5 Tahun 1990, PP Nomor 7 dan PP Nomor 8 Tahun 1999. Terdapat 29 (dua puluh Sembilan) spesies anggrek yang dilindungi dimana, terdapat 2 (dua) jenis anggrek yang terdapat di Cagar Alam Padang Luway yaitu Anggrek Hitam (Coelegyne pandurata Lindl.) dan Anggrek Tebu (Grammatophyllum speciosum). Anggrek Hitam termasuk spesies anggrek yang masuk dalam daftar Appendix II di CITES yang berarti Anggrek Hitam masuk daftar spesies yang tidak terancam kepunahan, tetapi mungkin terancam punah bila perdagangan terus berlanjut tanpa adanya pengaturan (Anonim, 2013).

Cagar Alam Padang Luway merupakan hutan kerangas yang sangat rentan terhadap gangguan kerusakan hutan dan kebakaran. Secara ekologis, hutan kerangas merujuk pada hutan di dataran rendah yang beriklim lembab dan panas, memiliki tanah podsol dan pasir kuarsa yang miskin hara, kaya akan asam silikat, dan memiliki $\mathrm{pH}$ rendah (Bruenig, 2017). Hutan kerangas mudah sekali mengalami gangguan akibat penebangan ataupun kebakaran. Ketika terdegradasi, hutan kerangas sulit untuk kembali ke kondisi semula (Kissinger, 2013), bahkan akan berkembang menjadi hutan kerangas yang terdegradasi, yang disebut padang (Bruenig, 1995) atau open degraded heath forest (Merbach et al. 2007), atau degraded kerangas forest (Bauer et al. 2008). Sementara area hutan kerangas yang terendam air karena kehilangan kemampuannya dalam menyerap air akan berkembang menjadi hutan kerapah (WWF, 2018).

Cagar Alam Padang Luway merupakan kumpulan dari beberapa tipe hutan yaitu tipe hutan kerangas, hutan tropis basah dan tipe hutan bergambut. Di dalam Cagar Alam Padang Luway terdapat beberapa daerah kersik (kersik = pasir) yang merupakan daerah penyebaran anggrek.

Anggrek merupakan nama umum untuk semua tumbuhan family Orchidaceae (keluarga anggrek anggrekan). Family ini merupakan salah satu grup terbesar di antara tumbuhan berbunga. Diperkirakan di seluruh dunia terdapat 15.000-20.000 spesies anggrek dengan 900 genus dan tersebar di 75 negara. Kurang lebih 5.000 spesies diantaranya tersebar di Indonesia (Halim, 2010). Keragaman morfologi bunga seperti, bentuk bunga, warna bunga, dan aroma bunga menjadi alasan mengapa anggrek menjadi salah satu tanaman hias yang banyak diminati konsumen, kolektor, produsen, dan pemulia tanaman hias (Handini, dkk. 2016)

Agar suatu areal bisa menjadi tempat hidup yang baik untuk anggrek tentu saja harus memiliki komponen ekologis yang dapat menunjang kehidupan anggrek. Komponen ekologis yang mempengaruhi kehidupan anggrek di habitatnya adalah komponen fisik (jenis tanah, suhu, kelembaban, intensitas cahaya, angin dan topografi) dan biotik (vegetasi lainnya, persen penutupan tajuk dan spesies tumbuhan inang). Kemudian salah satu indikator untuk melihat bahwa tempat tersebut merupakan tipe habitat yang sesuai atau "disenangi" (viable habitat) bagi pertumbuhan anggrek adalah dengan cara melihat penyebarannya dan juga melalui banyaknya jumlah rumpun yang ada di suatu lokasi pertumbuhan (Hartini, 2007).

Cagar Alam Padang Luway dengan luas 4.785,23 ha adalah salah satu Cagar Alam yang saat ini belum diketahui secara pasti pola atau bentuk penyebaran beberapa jenis anggrek yang terdapat di dalam kawasannya setelah pasca 
kebakaran tahun 2014. Berdasarkan permasalahan di atas penelitian untuk mengetahui sebaran anggrek di Cagar Alam Padang Luway menjadi penting dan relevan untuk dilakukan.

Adapun tujuan dari penelitian ini adalah untuk mengetahui sebaran alami anggrek dan mengetahui komposisi spesies anggrek di Cagar Alam Padang Luway dengan menggunakan metode analisis vegetasi. Sehingga diharapkan dapat diketahui distribusi dan sebaran jenis-jenis anggrek, tersedianya data dan informasi komposisi spesies anggrek di Cagar Alam Padang Luway dan Diharapkan penelitian ini dapat memberikan informasi dasar pertimbangan dalam pengelolaan Cagar Alam Padang Luway dimasa yang akan datang.

\section{METODA PENELITIAN}

Penelitian ini dilaksanakan di kawasan Cagar Alam Padang Luway tepatnya di Desa Sekolaq Darat Kecamatan Sekolaq Darat Kabupaten Kutai Barat Provinsi Kalimatan Timur. Pada bulan Maret-Juli 2017.

\subsection{Bahan dan Alat}

Alat dan bahan yang akan dipergunakan dalam penelitian ini adalah sebagai berikut : Peta lokasi Cagar Alam Padang Luway, Kamera foto yang akan dipergunakan sebagai alat dokumentasi, Lembar Kuesioner, untuk mendapatkan data primer, Komputer dan alat tulis lainnya untuk pengolahan data dan pembuatan skripsi, Data-data laporan pelaksanaan kegiatan pengelolaan Cagar Alam Padang Luway yang dilaksanakan Oleh Seksi Konservasi Wilayah II Tenggarong dan Balai KSDA Kalimantan Timur.

\subsection{Tempat dan Waktu}

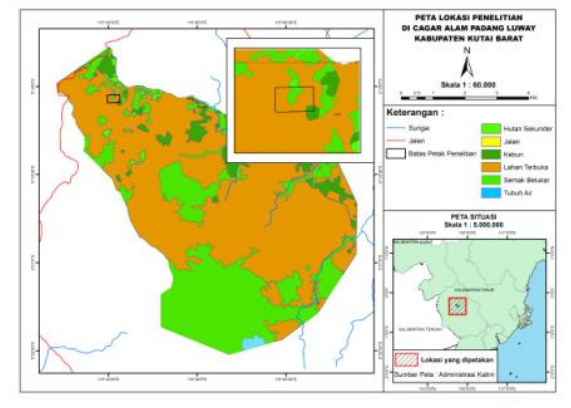

Gambar 1. Peta Lokasi Penelitian

\subsection{Pengumpulan Data}

Pengumpulan data di lapangan berupa data penyebaran anggrek dilakukan dengan cara inventarisasi dan identifikasi langsung di lokasi penelitian. Petak penelitian dibuat dengan ukuran $100 \mathrm{~m} \mathrm{x} 100 \mathrm{~m}$, kemudian di dalamnya dibuat jalur. Pada jalur dibuat sub-sub petak dengan ukuran $20 \mathrm{~m} \times 20 \mathrm{~m}$ untuk pengamatan anggrek yang tumbuh di batang pohon. Kemudian di dalam sub-sub petak dibuat lagi petak lebih kecil dengan ukuran $5 \mathrm{~m}$ x $5 \mathrm{~m}$ untuk pengamatan anggrek yang tumbuh di lantai hutan.

Pengamatan di dalam petak penelitian akan dilakukan dengan cara melihat dan mengamati anggrek yang terdapat di dalam petak pengamatan, didokumentasikan dan dicatat namanya, melihat dan mengamati inang anggrek yang terdapat di dalam petak pengamatan, 
didokumentasikan dan dicatat nama pohon inangnya, menghitung jumlah rumpun untuk memperoleh data tentang jumlah jenis dan jumlah populasi anggrek serta pengambilan titik koordinat anggrek dengan menggunakan GPS (Global Positioning System).

Pengumpulan data sekunder yang diperoleh dari Kantor atau Instansi terkait mengenai keadaan umum lokasi penelitian seperti letak wilayah dan kondisi fisik lingkungan.

\subsection{Analisis Data}

\subsubsection{Indeks Dispersi Morisita (I $\delta$ )}

Untuk mengetahui distribusi dan sebaran spasial anggrek di Cagar Alam Padang Luway menggunakan Indeks Dispersi Morisita (I $\delta$ ). dimana analisisnya menggunakan jumlah plot (n), jumlah individu yang ditemukan dalam satu plot $\left(\sum \mathrm{x}\right)$ dan kuandran jumlah individu yang ditemukan dalam satu plot $\left(\sum \mathrm{x}^{2}\right)$.

$$
\mathrm{I} \delta=\mathrm{n} \frac{\sum \mathrm{x}^{2}-\sum \mathrm{x}}{\left(\sum \mathrm{x}\right)^{2}-\sum \mathrm{x}}
$$

Pola Sebarannya ditunjukkan melalui perhitungan Mu dan Mc sebagai berikut :

$$
M u=\frac{X^{2} 0,975-n+\sum X i}{\left(\sum X i\right)-1}
$$

$$
M c=\frac{X^{2} 0,025-n+\sum X i}{\left(\sum X i\right)-1}
$$

Dimana :

$\mathrm{Mu} \quad$ : Indeks Morisitas untuk pola sebaran seragam

$\mathrm{X}^{20} 0,975$ : Nilai Chi-Square Tabel denga derajat bebas n-1 dan selang kepercayaan $97,5 \%$

Mc : Indeks Morisitas untuk pola sebaran mengelompok

$\mathrm{X}^{2} 0,025$ : Nilai Chi-Square Tabel dengan derajat bebas n-1 dan selang kepercayaan $2,5 \%$

n : jumlah plot

Xi : Jumlah individu yang ditemukan dalam plot

Kemudian menghitung Standar Indeks Morosita dengan menggunakan 4 formula yaitu :

Jika :

$I \delta \geq M c>1, I p=0,5+0,5\left[\frac{I \delta-M c}{n-M c}\right]$

$M c>I \delta \geq 1, I p=0,5\left[\frac{I \delta-1}{M u-1}\right]$

$1>I \delta>M u, I p=-0,5\left[\frac{I \delta-1}{M u-1}\right]$

$1>M u>I \delta, I p=-0,5+0,5\left[\frac{I \delta-M u}{M u}\right]$

Kemudian langkah yang terakhir adalah menentukan pola sebaran berdasarkan nilai Ip di atas. Jika Ip $<0$ maka pola sebarannya seragam, Ip $=0$ maka pola sebarannya acak dan jika Ip > 0 maka pola sebarannya mengelompok (Krebs, 1989).

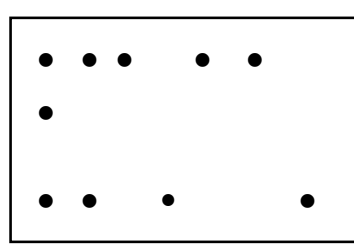

Acak

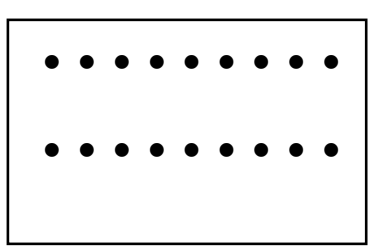

Seragam

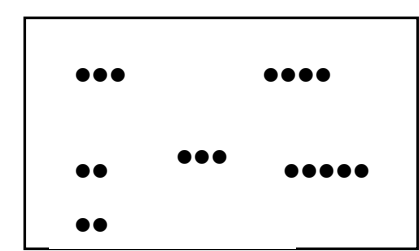

Mengelompok

Gambar 7. Pola Dasar Penyebaran Intern Individu dalam Suatu Populasi 


\subsubsection{Quadrat Analysis}

Quadrat Analysis dimana analisis ini berdasarkan titik-titik yang dianalisis menggunakan poligon serta menggunakan frekuensi distribusi atau Density Of Point di dalam satu set kotakkotak. Dengan menggunakan rumus :

$$
V M R=\frac{\text { Variance }}{\text { Mean }}
$$

Untuk mencari Varian:

$$
\frac{\sum_{i=1}^{n}(X i-\bar{X})^{2}}{N-1}=\frac{\sum_{i=1}^{n} X i-\left[\left(\sum X\right)^{2} / N\right]}{N-1}
$$

$$
\begin{array}{ll}
\text { Dimana : } & \\
\mathrm{Xi} & =\text { Jumlah Individu } \\
\mathrm{N} & =\text { Jumlah plot } \\
\text { Rasio } & =\text { Varian/Mean }
\end{array}
$$

Distribusi seragam yang seragam, variannya adalah 0 (rasio varian ratarata mendekati 0 );

Untuk distribusi acak, varians dan rata-ratanya adalah sama (rasio varian rata-rata sekitar 1);

Untuk distribusi berkerumun/bergerombol, variannya relatif besar (rasio varian rata-rata di atas 1) (Briggs, R. 2010).

\subsubsection{Indeks Nilai Penting (INP)}

Indeks Nilai Penting (INP) menunjukkan kepentingan suatu jenis tumbuhan serta peranannya dalam komunitas, dimana nilai penting pada vegetasi tingkat pohon, tiang dan pancang didapat dari hasil penjumlahan Kerapatan Relatif (KR), Frekuensi Relatif (FR) dan Dominansi Relatif (DR). Sedangkan pada vegetasi tingkat semai dan tumbuhan bawah didapat dari penjumlahan nilai Kerapatan Relatif (KR) dan Frekuensi Relatif (FR).

Indeks Nilai Penting (INP) anggrek diperoleh dengan cara menjumlahkan nilai kerapatan relatif dengan frekuensi relatif (KR + FR). Formula yang digunakan untuk menghitung parameter analisis vegetasi berdasarkan Bonham (2013).

\section{HASIL PENELITIAN DAN PEMBAHASAN}

Secara geografis Cagar Alam Padang Luway terletak pada garis equator $0^{\circ} 18^{\prime} 0^{\prime \prime}-0^{\circ} 22^{\prime} 30^{\prime \prime}$ Lintang Selatan dan $115^{\circ} 43^{\prime} 30^{\prime \prime}$ - 11546’30" Bujur Timur. Secara administratif Cagar Alam Padang Luway terletak di tiga kecamatan, yaitu Kecamatan Melak, Kecamatan Damai dan Kecamatan Sekolaq Darat, Kabupaten Kutai Barat, Provinsi Kalimantan Timur.

Cagar Alam Padang Luway merupakan kawasan konservasi berbagai jenis anggrek, dari hasil penelitian terdapat 2 pulau habitat anggrek yang terbesar di Cagar Alam Padang Luway. Dari hasil pengukuran di lapangan karateristik kedua pulau anggrek tersebut memiliki kelembaban udara yang tinggi $87 \%$ - $90 \%$ dengan suhu rata-rata $31,5^{\circ} \mathrm{C}$, memilki lapisan humus dan serasah yang tebal, penutupan tajuk yang rapat, dan terdapatnya beberapa jenis pohon inang anggrek. Beberapa jenis pohon inang anggrek tersebut adalah Nyerapi (Calophyllum glaucum), Pelawan (Tristania obovata), Brengganyi (Vaccinium varingiaefolium), Bekakang (Rhodomyrtus tomentosus), dan Kelebeti (Syzygium zeylanicum).

Menurut Iswanto (2002), pada umumnya anggrek membutuhkan suhu maksimum sekitar $28{ }^{\circ} \mathrm{C}$ dan suhu minimum sekitar $15^{\circ} \mathrm{C}$. Beberapa spesies anggrek alam yang tumbuh di daerah 
pegunungan hidup dan berkembang pada suhu rendah, yakni sekitar $5-10^{\circ} \mathrm{C}$. Ditinjau dari aspek suhu, anggrek terbagi atas tiga jenis yaitu: (1) Anggrek suhu dingin adalah anggrek yang tumbuh di daerah pegunungan di ketinggian 2000 $4000 \mathrm{~m}$ dpl. Anggrek jenis ini tumbuh baik pada suhu $15-21{ }^{\circ} \mathrm{C}$ saat siang hari dan $10-13^{\circ} \mathrm{C}$ saat malam hari, Anggrek suhu sedang adalah anggrek yang tumbuh di daerah yang mempunyai ketinggian antara $750-2000 \mathrm{~m}$ dpl. Anggrek jenis ini tumbuh baik pada suhu $21-32{ }^{\circ} \mathrm{C}$ saat siang hari dan $13-18{ }^{\circ} \mathrm{C}$ saat malam hari. Anggrek suhu panas adalah anggrek yang tumbuh di dataran rendah yang memiliki ketinggian antara $0-750 \mathrm{~m}$ dpl. Anggrek jenis ini tumbuh baik pada suhu $26-35^{\circ} \mathrm{C}$ saat siang hari dan $18-$ $24{ }^{\circ} \mathrm{C}$ saat malam hari. Anggrek yang tumbuh di cagar alam Padang Luway termasuk jenis anggrek suhu panas.

Berdasarkan hasil penelitian ditemukan 20 jenis anggrek. Pulau 1 (satu) terdapat 214 individu dari 14 jenis anggrek dimana didominasi oleh anggrek hitam (Coelogyne pandurata Lind.) sedangkan di pulau 3 (tiga) terdapat 174 individu anggrek dengan jumlah jenisnya adalah 12 jenis anggrek yang didominasi oleh anggrek meteor/pandurata bulat (Coelogyne foerstermannii), anggrek hitam (Coelogyne pandurata Lind.) dan anggrek merpati putih (Dendrobium cruminatum).

Anggrek merpati putih lebih banyak ditemukan pada areal terbuka dan areal hutan yang pernah mengalami kebakaran. Anggrek ini banyak ditemukan di pulau 3 yang dulunya adalah pulau 4 karena mengalami kebakaran pada tahun 2014 pulau 4 hanya menyisakan sedikit vegetasi pohon, sekarang didominasi oleh alang-alang, kantong semar dan Anggrek merpati putih.
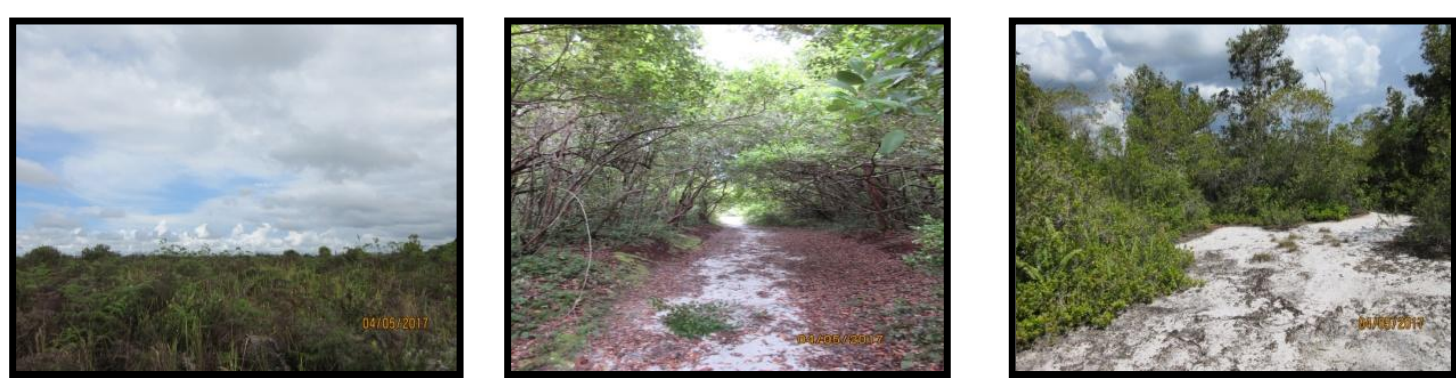

Gambar 2. Kondisi Lokasi Penelitian

\section{a. Indeks Dispersi Morisita (Iס)}

Hasil analisis sebaran anggrek di

Cagar Alam Padang Luway dengan menggunakan Indeks Dispersi Morosita dapat dilihat pada Tabel 1 di bawah ini :

Tabel 1 Sebaran Anggrek di Cagar Alam Padang Luway Berdasarkan Indeks Dispersi Morisita

\begin{tabular}{lllllll}
\hline No. & Nama Ilmiah & $\mathrm{Id}$ & $\mathrm{Mu}$ & $\mathrm{Mc}$ & $\mathrm{Ip}$ & Keterangan \\
\hline 1 & Dendrobium aloifolium & 1.51 & 0.72 & 1.40 & 0.01 & Mengelompok \\
2 & Acriopsis indica & 5.00 & -1.30 & 4.34 & 1.50 & Mengelompok \\
3 & Renatera elogata & 1.82 & 0.37 & 1.91 & 0.45 & Mengelompok \\
4 & Bulbophyllum epicrianthes & 2.10 & 0.51 & 1.72 & 0.01 & Mengelompok \\
5 & Bulbophyllum vaginatum & 3.33 & 0.14 & 2.25 & 0.03 & Mengelompok
\end{tabular}




\begin{tabular}{lllllll}
6 & Dendrobium cruminatum & 2.05 & 0.89 & 1.15 & 0.03 & Mengelompok \\
7 & Bulbophyllum macrochilum & 3.33 & -2.46 & 6.01 & 0.23 & Mengelompok \\
8 & Dendrobium sp & 2.82 & 0.42 & 1.84 & 0.03 & Mengelompok \\
9 & Bulbophyllum odoratum & 3.33 & -1.30 & 4.34 & 0.35 & Mengelompok \\
10 & Coelogyne foerstermannii & 3.46 & 0.88 & 1.17 & 0.07 & Mengelompok \\
11 & Coelogyne pandurata & 1.79 & 0.95 & 1.07 & 0.02 & Mengelompok \\
12 & Bromheadia finlaysoniana & 2.18 & 0.31 & 2.00 & 0.01 & Mengelompok \\
13 & Coelogyne rochusseni de Vriese & 1.67 & -1.30 & 4.34 & 0.10 & Mengelompok \\
14 & Cleisostoma subulatum & 3.21 & 0.01 & 2.43 & 0.03 & Mengelompok \\
15 & Dendrobium acuminatissimum & 0.00 & -5.91 & 11.02 & -0.07 & Seragam \\
16 & Dendrobium leonis & 3.33 & -1.30 & 4.34 & 0.35 & Mengelompok \\
17 & Grammatophyllum speciosum & 0.00 & -5.91 & 11.02 & -0.07 & Seragam \\
18 & Bulbophyllum sp & 0.00 & 0.00 & 0.00 & 0.00 & Acak \\
19 & Dendrobium sp & 0.00 & 0.00 & 0.00 & 0.00 & Acak \\
20 & Bulbophyllum beccarii & 10.00 & -5.91 & 11.02 & 0.45 & Mengelompok \\
\hline
\end{tabular}

Dari Tabel 1 di atas dapat diketahui bahwa sebaran anggrek di Cagar Alam Padang Luway berdasarkan Indeks Dispersi Morisita rata-rata mengelompok, namun ada juga yang acak dan seragam. Terdapat 16 jenis anggrek yang mengelompok dengan Ip $>0$, jenisjenis yang sebarannya mengelompok adalah Dendrobium aloifolium, Acriopsis indica, Renatera elogata, Bulbophyllum epicrianthes, Bulbophyllum vaginatum, Dendrobium cruminatum, Bulbophyllum macrochilum, Dendrobium sp, Bulbophyllum odoratum, Coelogyne foerstermannii, Coelogyne pandurata, Bromheadia finlaysoniana, Coelogyne rochusseni de Vriese, Cleisostoma subulatum, Dendrobium leonis dan Bulbophyllum beccarii. Untuk anggrek yang sebarannya acak dengan Ip $=0$ ada dua jenis, yaitu Bulbophyllum sp dan Dendrobium sp, sedangkan anggrek yang sebarannya seragam dengan Ip $<0$ terdapat dua jenis yaitu Dendrobium acuminatissimum dan Grammatophyllum speciosum.

\section{b. Quadrat Analysis}

Dari hasil analisis sebaran Anggrek menggunakan Quadrat Analysis maka hasil yang diperoleh dapat di lihat pada Tabel 2 di bawah ini :

Tabel 2 Sebaran Anggrek di Cagar Alam Padang Luway Berdasarkan Indeks Quadrat Analysis

\begin{tabular}{clcccl}
\hline No. & \multicolumn{1}{c}{ Nama Ilmiah } & V & MR & V/MR & Keterangan \\
\hline 1 & Dendrobium aloifolium & 6.27 & 2.00 & 3.13 & Mengelompok \\
2 & Acriopsis indica & 0.93 & 2.00 & 0.47 & Acak \\
3 & Renatera elogata & 2.40 & 2.00 & 1.20 & Mengelompok \\
4 & Bulbophyllum epicrianthes & 4.06 & 2.00 & 2.03 & Mengelompok \\
5 & Bulbophyllum vaginatum & 2.77 & 2.00 & 1.38 & Mengelompok \\
6 & Dendrobium cruminatum & 56.49 & 2.00 & 28.24 & Mengelompok \\
7 & Bulbophyllum macrochilum & 0.46 & 2.00 & 0.23 & Acak \\
8 & Dendrobium sp & 4.46 & 2.00 & 2.23 & Mengelompok
\end{tabular}




\begin{tabular}{clcccl}
9 & Bulbophyllum odoratum & 0.71 & 2.00 & 0.36 & Acak \\
10 & Coelogyne foerstermannii & 106.32 & 2.00 & 53.16 & Mengelompok \\
11 & Coelogyne pandurata & 188.32 & 2.00 & 94.16 & Mengelompok \\
12 & Bromheadia finlaysoniana & 2.54 & 2.00 & 1.27 & Mengelompok \\
13 & Coelogyne rochusseni de Vriese & 0.49 & 2.00 & 0.24 & Acak \\
14 & Cleisostoma subulatum & 2.18 & 2.00 & 1.09 & Mengelompok \\
15 & Dendrobium acuminatissimum & 0.18 & 2.00 & 0.09 & Seragam \\
16 & Dendrobium leonis & 0.71 & 2.00 & 0.36 & Acak \\
17 & Grammatophyllum speciosum & 0.18 & 2.00 & 0.09 & Seragam \\
18 & Bulbophyllum sp & 0.10 & 2.00 & 0.05 & Seragam \\
19 & Dendrobium sp & 0.10 & 2.00 & 0.05 & Seragam \\
20 & Bulbophyllum beccarii & 0.40 & 2.00 & 0.20 & Acak \\
\hline
\end{tabular}

Dari tabel di atas ada sepuluh jenis Anggrek yang sebarannya mengelompok memiliki varian yang lebih besar dengan rasio varian rata - rata di atas 1 . Jenisjenis Anggrek yang penyebarannya mengelompok adalah Dendrobium aloifolium, Renatera elogata, Bulbophyllum epicrianthes, Bulbophyllum vaginatum, Dendrobium cruminatum, Dendrobium sp., Coelogyne foerstermannii, Coelogyne pandurata Lind., Bromheadia finlaysoniana dan Cleisostoma subulatum.

Jenis-jenis Anggrek yang penyebarannya acak/random dimana varians dan rerata adalah sama rasio varian rata-rata sekitar 1 adalah Acriopsis indica, Bulbophyllum macrochilum, Bulbophyllum odoratum, Coelogyne rochusseni de Vriese, Dendrobium leonis dan Bulbophyllum beccarii.

Jenis - jenis Anggek yang penyebarannya seragam memiliki varian 0 dimana rasio varian rata-rata mendekati 0 adalah Dendrobiumacuminatissimum, Grammatophyllum speciosum, Bulbophyllum sp dan Dendrobium sp.

Dari Tabel 1 dan Tabel 2 di atas terdapat perbedaan distribusi sebaran Anggrek Acriopsis indica. Pada hasil perhitungan Indeks Dispersi Morisita (Tabel 1) sebaran Anggrek Acriopsis indica mengelompok dengan Ip 1,50 yang lebih besar dari 0 , sedangkan pada
Quadrat Analysis (Tabel 2) sebaran Anggrek Acriopsis indica acak/random varians dan rerata 0,47 adalah sama rasio varian rata - rata sekitar.

Sebaran Bulbophyllum macrochilum pada Tabel 1 mengelompok Ip 0,23 yang lebih besar dari 0 , sedangkan pada Tabel 2 Bulbophyllum macrochilum tersebar secara acak/random varians dan rerata 0,23 adalah sama rasio varian rata - rata sekitar 1 .

Sebaran Bulbophyllum odoratum pada Tabel 1 mengelompok dengan Ip 0,35 yang lebih besar dari 0 , sedangkan pada Tabel 2 Bulbophyllum odoratum tersebar secara acak/random varians dan rerata 0,36 adalah sama rasio varian rata rata sekitar 1.

Sebaran Coelogyne rochusseni de Vriese pada Tabel 1 mengelompok dengan Ip 0,01 yang lebih besar dari 0, sedangkan pada Tabel 2 Coelogyne rochusseni de Vriese tersebar secara acak/random varians dan rerata 0,24 adalah rasio varian rata-rata sekitar 1 .

Sebaran Dendrobium leonis pada tabel 1 mengelompok dengan Ip 0,35 yang lebih besar dari 0, sedangkan pada Tabel 2 Dendrobium leonis tersebar secara acak/random varians dan rerata 0,36 adalah rasio varian rata-rata sekitar 1. 
Sebaran Bulbophyllum sp pada Tabel 1 tersebar acak/random dengan Ip sama dengan 0 , sedangkan pada tabel 2 Bulbophyllum sp tersebar seragam varians dan rerata 0,05 adalah rasio varians rata - rata mendekati 0 .

Sebaran Dendrobium sp pada Tabel 1 tersebar acak/random dengan Ip sama dengan 0, sedangkan pada Tabel 2 Dendrobium sp. tersebar seragam varians dan rerata 0,05 adalah rasio varians rata rata mendekati 0 .

Sebaran Bulbophyllum beccarii pada Tabel 1 tersebar mengelompok dengan Ip 0,45 yang lebih besar dari 0, sedangkan pada Tabel 2 Bulbophyllum beccarii tersebar secara acak/random varians dan rerata 0,20 adalah rasio varian rata-rata sekitar 1 .

Perbedaan tersebut menunjukkan bahwa terdapat kelemahan pada quadrat analysis (Briggs, 2010) yaitu :

a. Hasil mungkin tergantung pada ukuran kuadrat dan orientasi (masalah unit areal yang dapat dimodifikasi) seperti uji ukuran yang berbeda (atau orientasi) untuk menentukan efek dari masing - masing tes pada hasil, sebagai contoh jika ukuran kuadrat terlalu besar mungkin mengandung terlalu banyak poin, sebaliknya Jika terlalu kecil, mereka mungkin hanya mengandung beberapa poin.

b. Adalah ukuran dispersi, dan bukan pola, karena dasar utamanya pada kepadatan titik, dan bukan pengaturannya dalam kaitannya satu sama lain. Sebagai contoh, analisis kuadrat tidak dapat membedakan antara dua pola yang jelas berbeda;

c. Hasil dalam ukuran tunggal untuk seluruh distribusi, sehingga variasi dalam wilayah tidak dikenali (bisa mengelompokkan lokal di beberapa daerah, tetapi tidak secara keseluruhan).

d. Hasil mungkin tergantung pada ukuran kuadrat dan orientasi (masalah unit areal yang dapat dimodifikasi) seperti uji ukuran yang berbeda (atau orientasi) untuk menentukan efek dari masing - masing tes pada hasil, sebagai contoh jika ukuran kuadrat terlalu besar mungkin mengandung terlalu banyak poin, sebaliknya Jika terlalu kecil, mereka mungkin hanya mengandung beberapa poin.

e. Adalah ukuran dispersi, dan bukan pola, karena dasar utamanya pada kepadatan titik, dan bukan pengaturannya dalam kaitannya satu sama lain. Sebagai contoh, analisis kuadrat tidak dapat membedakan antara dua pola yang jelas berbeda;

f. Hasil dalam ukuran tunggal untuk seluruh distribusi, sehingga variasi dalam wilayah tidak dikenali (bisa mengelompokkan lokal di beberapa daerah, tetapi tidak secara keseluruhan).

\section{c. Indeks Nilai Penting (INP)}

Dari hasil analisis Indeks Nilai Penting jenis-jenis anggrek di Cagar Alam Padang Luway disajikan pada Tabel 3.

Tabel 3 Indeks Nilai Penting (INP) Jenis-jenis Anggrek di Cagar Alam Padang Luway

\begin{tabular}{clcccc}
\hline No. & Nama Ilmiah & K/Ha & KR \% & FR \% & INP \\
\hline 1 & Dendrobium aloifolium & 520 & 6.684 & 8.571 & 15.255 \\
2 & Acriopsis indica & 80 & 1.028 & 2.857 & 3.885 \\
3 & Renatera elogata & 240 & 3.085 & 7.143 & 10.228 \\
4 & Bulbophyllum epicrianthes & 300 & 3.856 & 5.714 & 9.570 \\
5 & Bulbophyllum vaginatum & 180 & 2.314 & 4.286 & 6.599 \\
6 & Dendrobium cruminatum & 1320 & 16.967 & 11.429 & 28.395
\end{tabular}




\begin{tabular}{clcccc}
7 & Bulbophyllum macrochilum & 60 & 0.771 & 2.857 & 3.628 \\
8 & Dendrobium sp & 260 & 3.342 & 4.286 & 7.628 \\
9 & Bulbophyllum odoratum & 80 & 1.028 & 2.857 & 3.885 \\
10 & Coelogyne foerstermannii & 1220 & 15.681 & 10.000 & 25.681 \\
11 & Coelogyne pandurata & 2820 & 36.247 & 11.429 & 47.675 \\
12 & Bromheadia finlaysoniana & 220 & 2.828 & 7.143 & 9.971 \\
13 & Coelogyne rochusseni de Vriese & 80 & 1.028 & 4.286 & 5.314 \\
14 & Cleisostoma subulatum & 160 & 2.057 & 4.286 & 6.342 \\
15 & Dendrobium acuminatissimum & 40 & 0.514 & 2.857 & 3.371 \\
16 & Dendrobium leonis & 80 & 1.028 & 2.857 & 3.885 \\
17 & Grammatophyllum speciosum & 40 & 0.514 & 2.857 & 3.371 \\
18 & Bulbophyllum sp & 20 & 0.257 & 1.429 & 1.686 \\
19 & Dendrobium sp & 20 & 0.257 & 1.429 & 1.686 \\
20 & Bulbophyllum beccarii & 40 & 0.514 & 1.429 & 1.943 \\
\hline
\end{tabular}

Berdasarkan hasil analisis jenis anggrek yang dominan atau memiliki nilai INP tertinggi adalah Anggrek Hitam (Coelogyne pandurata Lind.) 47,675\% sedangkan yang paling rendah adalah Anggrek Bulbophylum (Bulbophylum sp.) $1,686 \%$ dan Anggrek Anyaman Jarum (Dendrobium sp) 1,686\%.

Tingginya INP Anggrek Hitam di Cagar Alam Padang Luway dipengaruhi oleh hutan yang masih terjaga sehingga kerapatan relatifnya sangat tinggi juga. Faktor-faktor lingkungan seperti suhu udara, suhu tanah, kelembaban tanah dan intensitas cahaya sangat mempengaruhi pertumbuhan jenis anggrek.

Jenis-jenis anggrek yang memiliki INP terbesar merupakan jenis-jenis yang paling mampu menyesuaikan diri terhadap kondisi lingkungan tempat tumbuh atau merupakan jenis yang dominan. Artinya jenis-jenis yang dominan tersebut mampu memanfaatkan sumber daya lingkungan dan tempat tumbuh secara optimal.

Dari hasil pengamatan di lapangan, kawasan Cagar Alam Padang Luway mempunyai karateristik flora yang unik yaitu pohon yang tumbuh pada kawasan tersebut berukuran kecil dan umumnya mempunyai tinggi $2-6 \mathrm{~m}$ dengan bentuk daun yang kecil dan tidak terlalu lebar sehingga cahaya dapat menembus sampai ke lantai hutan dan karakter kulit batang yang kasar dan beralur merupakan tempat tumbuh yang baik bagi anggrek epifit (Budiman, dkk., 2016). Selain itu semua pohon nampak berhabitus perdu yang dikarenakan kondisi tanah yang bertipe kerangas yang miskin akan unsur hara walaupun dari segi lain kawasan ini kaya akan bahan organik gambut.

Pohon dengan tipe kulit batang kasar atau retak memiliki jenis anggrek yang lebih banyak dibandingkan dengan pohon yang memiliki tipe kulit batang yang licin. Kulit batang yang kasar dan retak merupakan habitat yang cocok untuk melekatnya spora anggrek. Selain karena karakter fisik kulit batang, faktor lain juga mempengaruhi kekeyaan serta kelimpahan jenis anggrek diantaranya kelembaban, daya serap dan nilai Ph kulit batang. Hanya sedikit jenis anggrek yang epifit pada kulit batang yang memiliki $\mathrm{Ph}$ tinggi (Gradstein, 2010).

\section{KESIMPULAN}

Distribusi dan sebaran anggrek di Cagar Alam Padang Luway berdasarkan analisis Indeks Dispersi Morisita ratarata mengelompok, namun ada juga yang acak dan seragam. Sedangkan hasil 
analisis dengan Quadrat Analysis menghasilkan sepuluh jenis anggrek yang sebarannya mengelompok, anggrek yang penyebarannya acak/random enam jenis dan anggrek yang penyebarannya seragam ada empat jenis.

\section{UCAPAN TERIMA KASIH}

Terimakasih diucapkan kepada Balai Konservasi Sumber Daya Alam (BKSDA) Kalimantan Timur yang telah membantu selama pengumpulan data, khususnya kepada Bapak Sumarso, S.Hut. sebagai Kepala Resort Cagar Alam Padang Luway dan Bapak Didimus yang telah mendampingi selama melaksanakan penelitian.

\section{DAFTAR PUSTAKA}

Anonim. 2013. Rencana Pengelolaan Jangka Panjang Cagar Alam Padang Luway Periode 2014 2023. 2013. Balai Konservasi Sumber Daya Alam Kaltim. Samarinda.

Bauer, U., Holger F.B., Walter F. 2008. Harmless nectar source or deadly trap: Nepenthes pitchers are activated by rain, condensation and nectar. Proceedings of the Royal Society B: Biological Sciences. 275(1632): 259-65.

Bonham, C. D. (2013). Measurements for Terestrial Vegetation. Colorado: Willey-Black Well

Briggs, R. 2010. Point Pattern Analysis Using Spatial Inferential Statistics. Tersedia di https://www.utdallas.edu/ briggs/h enan/7pointPat.ppt. $17 \quad$ Februari
2017. Diakses pada 10 November 2017

Bruenig EF. 2017. Conservation and Management of Tropical Rain Forest: An Integrated Approached to Sustainability. Hamburg (DE): CABI.

Budiman, Fidelis K., Sumarso. 2016. Diversitas dan Karakter Kulit Batang Pohon Inang Anggrek Hitam (Coelogyn pandurata Lind.) di Kawasan Cagar Alam Kersik Luway. Jurnal Pembangunan dan Alam Lestari (J-PAL). Vol 7. No. 1. Hal; $11-14$

Febriliani, S. N. M., Muslimin. 2013. Analisis Vegatasi Habitat Anggrek Di sekitar Danau Tambing Kawasan Taman Nasional Lore Lindu. Warta Rimba, I.

Gradstein, S. R., H. Culmsee, 2010. Bryophyte Diversity On Tree Trunks in Montane Forest of Central Sulawesi, Indonesia. Tropical Bryology.

Halim, S. 2010. Analisis Ekologidan Bentuk Sebaran Spasial Populasi Anggrek Hitam (Coelegyne pandurata Lindl.) Di Cagar Alam Padang Luway Kabupaten Kutai Barat Kalimantan Timur. Tesis Pascasarjana Institut Pertanian Bogor. Bogor 80 halaman.

Handini, A. S., Sukma D., Sudarsono., 2016. Analisis Keragaman Morfologi dan Biokimia pada Anggrek Phalaenopsis (Orchidaceae). Jurnal Agron Indonesia. Vol. 44 No. 1. Hal : 62 67. 
Hartini, S. 2007. Keragaman Flora dari Monumen Alam Kersik Luway, Kalimantan Timur. Jurnal Biodiversitas. Vol. 8 No. 1. Hal 67 $-72$

Iswanto, H. 2002. Petunjuk Perawatan Anggrek. Jakarta Agromedia Pustaka.

Kissinger. 2007. Kemampuan dan pola tangkap kantong semar (Nepenthes sp.) terhadap jenis-jenis serangga pada hutan kerangas. Jurnal Hutan Tropis Borneo. 8 (20): 17-21.

Krebs, C.J. 1989. Ecological Methodology. Harper Collins Publisher, Inc. New York.

Merbach, M.A., Georg Z., Brigitte F., Dennis M., Webber E.B., Ulrich M.
2007. Why a carnivorous plant cooperates with an ant-selective defense against pitcher-destroying weevils in the myrmecophetic pitcher plant Nepenthes bicalcarata Hook F. Ecotropica. 13: 45-56.

WWF. 2018. Sundaland Heath Forests. Tersedia pada: https://www.worldwildlife.org/ecor egons/im0161. Diakses pada 14 Juni 2019 